\title{
Influence of genotype on the quality of sheep leather
}

\section{Manuel Antônio Chagas Jacinto ${ }^{1}$, Fernando Miranda de Vargas Junior ${ }^{2}$, Charles Ferreira Martins ${ }^{3}$, Guilherme dos Santos Pinto ${ }^{4}$, Fernando Alvarenga Reis ${ }^{5}$, Alexandra Rocha de Oliveira 6}

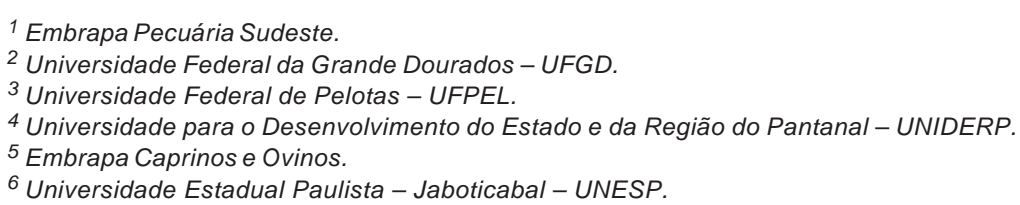

ABSTRACT - The objective of this study was to evaluate the influence of crossings between sheep breeds on the intrinsic quality of leather. It was used the skins of 36 lambs (18 females and 18 males), resulting from crosses between ewes of a native breed from the Brazilian state of Mato Grosso do Sul and rams of the same native breed as well as the Texel and Santa Inês genetic groups. The animals were raised in confinement until slaughter weight, from 28 to $32 \mathrm{~kg}$. After slaughter, samples were taken from the skins for histological analysis. The skins were tanned with chromium, retanned and greased. It was taken from the leather samples for electromicrographs and for tests for tensile and tear strength (intrinsic quality). Morphological aspects from the skin as well as from the leather help to understand the results found and they evidence that breeds or crossings among breeds interfere in the intrinsic quality of leather and skin of sheep.

Key Words: electromicrograph, photomicrograph, physical-mechanical, skin, tanning

\section{Introduction}

Introduced to Brazil by the colonizers, sheep and goats adapted well to the environmental conditions in the semi-arid regions in the country (Leite \& Vasconcelos, 2000), leading to the emergence of some local breeds that, although rustic, are not as productive as the original breeds which they developed from (Figueiredo et al., 1990). This is the case of sheep native to the state of Mato Grosso do Sul, which compose a genetic bank that has been relatively underexploited because of their genetic segregation by climate as well as the water regime and vegetation peculiar to the Pantanal region. Indeed, these breeds were at risk of extinction until recently.

Based on an exploratory study initiated in 2005, a group of researchers from the Centro Tecnológico de Ovinocultura (CTO) at Universidade Anhaguera-UNIDERP, Universidade Federal da Grande Dourados (UFDG), Universidade Federal de Mato Grosso do Sul (UFMS) and Empresa Brasileira de Pesquisa Agropecuária (Embrapa CNPGC, CPPSE and CNPC) have been conducting studies with a genetic group of sheep native to the Pantanal wetlands region. As part of this research program, undefined breed (UB) animals were acquired from various breeders in the upper and lower Pantanal region. These animals, regionally called "ovelha crioula do pantanal" ("Pantanal creole sheep"), are still found in large numbers in the more isolated ranches in the region, without any control of reproduction or sanitary conditions, thus having existed for long periods under natural selection conditions (Gomes et al., 2007). The main focus of the ongoing studies is to discover the potential of this genetic group for production of meat and skins, particularly through crossing with other breeds.

The skins of these animals are still considered a byproduct by herders and slaughterhouses; therefore they are relegated to a secondary position. However, if they were of good quality, their value could make up a not negligible portion of the value of the carcass (Jacinto, 2001). The quality of sheep leather is influenced by the breed and age of the animals (intrinsic quality) and by the marks on the skins acquired during the lifetime of the animal (extrinsic quality) (Jacinto et al., 2004).

Hair sheep leather is mechanically more resistant than that from wool sheep (Snyman \& Jackson-Moss, 2000), but this superiority declines with an increasing fraction of the wool sheep breed in the crosses (Villarroel et al., 2004). 
The objective of this study was to assess the influence of genotype (Mato Grosso Native, Texel $\times$ Native and Santa Inês $\times$ Native) on the quality of sheep leather.

\section{Material and Methods}

The experiment was conducted on Fazenda Escola Três Barras, part of the Centro Tecnológico de Ovinocultura (CTO) at Universidade para o Desenvolvimento do Estado e da Região do Pantanal (UNIDERP), located in the municipality of Campo Grande, Mato Grosso do Sul.

It was used the skins of 36 animals, 18 males and 18 females, 6 of each sex from three genetic groups, resulting from crossing rams of the Native (Pantanal Creole), Texel and Santa Inês breeds with ewes of the Native breed. The animals used were randomly chosen from the total number available from the same breeding season and were kept in confinement before slaughter.

The animals were confined in a large barn with cement floor covered by a layer of sawdust, they received water and uniform complete feed, in a sufficient quantity so that the leftover corresponded up to $10 \%$ of the feed offered. The feed was composed of sorghum silage (Sorghum vulgare) for volume and concentrated feed formulated to meet the nutritional requirements of lambs for average weight gain of 250 g/day (NRC, 1985).

The weight of the animals was monitored until it was within the range of 28 to $32 \mathrm{~kg}$, when they were slaughtered, always with at least 12 hours of fasting (solids and liquids) beforehand. Skin samples were collected immediately after they were flayed. These samples were fixed, sliced in a microtone, subjected to specific staining and mounted on permanent slides for analysis using an optical microscope, according to Jacinto et al. (2004).

The animals were slaughtered at a commercial slaughterhouse authorized by Federal Inspection Service, located in Campo Grande, Mato Grosso do Sul. The carcasses were flayed by hand and the skins were preserved with sodium chloride and boric acid, according to the methodology of Kanagaraj et al. (2005). The skins were stored in the shade, stacked alternately with the fur side up and down, until the moment of processing. The skins were tanned and the leather retanned at the Centro Tecnológico do Couro in Campo Grande, Mato Grosso do Sul, through the steps of soaking, liming, deliming, bating, pickling, tanning, retanning and fatliquoring, according to the method of Silva Sobrinho \& Jacinto (2007).

The samples for analysis of intrinsic quality were removed from the dorsal region of the leather with the aid of a hydraulic press and knife, so that the samples had the dimensions determined by ISO 3376 (2002) standard for tensile strength and ISO 3377-2 (2002) for tear strength. The samples were acclimatized according to ISO 2419 (2006) and the thickness, used in calculating the tensile and tear strengths, was measured as specified in ISO 2589 (2002). The extrinsic quality of the samples was assessed according to the commercial classification, based on the presence or absence of defects.

The experimental design was completely randomized with groups and sub-groups, the groups consisting of combinations of the three breeds with the two sexes and the sub-groups consisting of two directions of removing the samples (parallel and perpendicular to the backbone), using six repetitions. The means of the data were compared by the Tukey test at $5 \%$ probability, calculated with the PROC GLM program from SAS (2002-2003).

\section{Results and Discussion}

The average thickness of the leather from the females of the Native and Texel $\times$ Native groups in the tensile and tear strength tests was higher $(\mathrm{P}<0.05)$ than for the males. Among the males of the Santa Inês $\times$ Native genetic group, the opposite occurred, with thicker leather on average $(\mathrm{P}<0.05)$ than for the females (Table 1$)$. This might be related to the fact that the Native $\times$ Santa Inês sheep are hair sheep, acquiring this trait from the Santa Inês component.

In the evaluation between the sexes of the animals, there was no significant difference $(\mathrm{P}>0.05)$ in the thickness of the leather samples $(\mathrm{mm})$ by the tensile strength test between the males and females, whose values were $1.73 \pm 0.01$ and $1.72 \pm 0.01$, respectively. However, the thickness (mm) of the leather samples from the males by the tear strength test $(1.67 \pm 0.01)$ was significantly greater $(\mathrm{P}<0.05)$ than that of the females $(1.64 \pm 0.01)$.

Genetic group also influenced $(\mathrm{P}<0.05)$ the average thickness of the leather samples used to calculate the tensile strength (Table 2). The same was true for tear strength, in which the leather samples from the Native $x$ Santa Inês group were thicker $(\mathrm{P}<0.05)$ than those from the other two groups. Some authors, when studying the skins of sheep (Villarroel et al., 2004), goats (Dal Monte et al., 2004) and both these animals (Oliveira et al., 2008; Oliveira et al., 2007), did not note significant effects of the genetic group or the direction in which the sample was taken to on the leather thickness.

The tensile strengths of the leather samples from the Native and Native $\times$ Santa Inês groups were greater than those 
of the Native $\times$ Texel group. A similar outcome was observed for the tear strength test, in which the obtained values were approximately $40.5,36.2$ and $42.0 \mathrm{~N} / \mathrm{mm}$, respectively, for the three groups studied. Villarroel et al. (2004) also noted significantly better $(\mathrm{P}<0.05)$ tensile and tear strengths of leather samples from the Santa Inês $\times$ Undefinied Breed genotype in comparison with the Texel $\times$ WDB genotype.

An important aspect of the production of sheep skins is the ratio between the density of the collagen fibers and the follicular density, which are inversely proportional, i.e., the greater the density of the primary follicles bearing the fibers (wool or hair), the lower the density of the collagen fibers (Jacinto, 2004). Associated with the primary follicles, there are several secondary follicles that also contribute to reduce the density of collagen fibers.

In the images of the histological sections cut parallel to the skin surface, there were well-defined arrangements, called "hair follicle units" (Figure 1), formed by the primary follicle (1), sebaceous gland (2), hair erector muscle (3) and sweat gland duct (arrow).

The sheep of the Native breed had fewer hair follicle units than did Texel $\times$ Native genetic group, but more than Santa Inês $\times$ Native group. Santa Inês $\times$ Native crossbred sheep are covered with hair, whereas the animals of the Native and Texel $\times$ Native groups grow wool (Figure 2 ).

Leather samples from the Santa Inês $\times$ Native group were more resistant to tensile and tearing strength than those of the Texel $\times$ Native group $(\mathrm{P}<0.05)$. This superiority can be related to the smaller quantity of skin constituents (follicles, gland and erector muscles) and greater quantity of collagen fiber bundles (Figure 2). The greater the number of primary and secondary hair follicles, the more space is necessary to hold the glands, reducing the space available for collagen fiber bundles, and consequently the resistance of the skin and leather to tearing and stretching (Jacinto et al., 2004).

The tensile strength was higher $(\mathrm{P}<0.05)$ in the parallel towards to the backbone, whereas the tear strength was greater in the perpendicular direction (Table 3). These values were higher than the minimums reported in the literature on shoe leather (BASF, 2004), which were greater than $20 \mathrm{~N} / \mathrm{mm}^{2}$ and $35 \mathrm{~N} / \mathrm{mm}$, respectively. Similar results were reported by Ferrandiz-Gomez et al. (1993) for cow, sheep and goat leather and by Oliveira et al. (2008) and Oliveira et al. (2007) for sheep and goat leather. However, Villarroel et al. (2004) did not find any effect of the direction of the sample in relation to the backbone $(\mathrm{P}>0.05)$ on the average tensile and tear strength values for sheep leather.

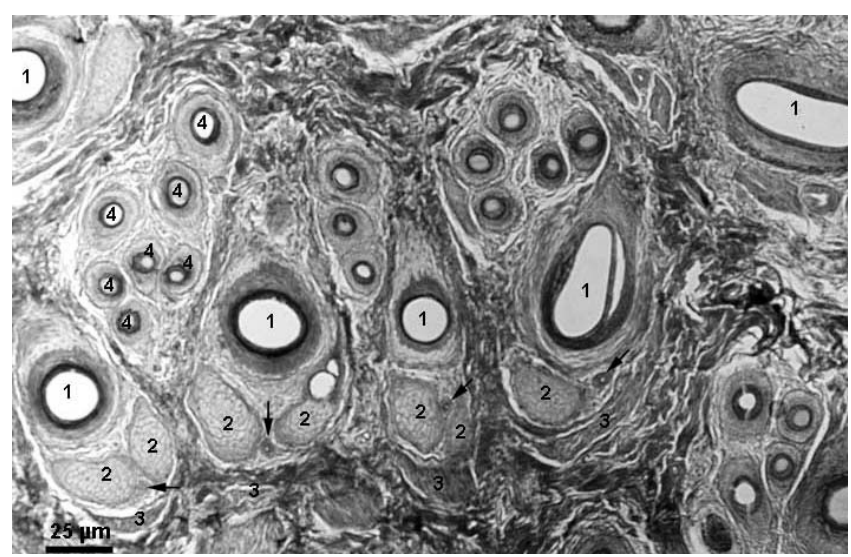

1 = primary follicle; 2 = sebaceous gland; 3 = hair erector muscle; 4 = secondary follicle; arrow $=$ sweat gland duct. Hair follicle unit $=1+2+3+$ arrow. Staining $=$ Masson's trichrome.

Figure 1 - Photomicrograph of a section cut parallel to the skin surface of $1 / 2$ Suffolk $+1 / 2$ Santa Inês sheep (Jacinto, 2010).

Table 1 - Leather thickness by the tensile strength test $(\mathrm{mm})$ and tear strength test $(\mathrm{mm})$ of males and females in the genetic groups

\begin{tabular}{|c|c|c|c|c|c|c|}
\hline & \multicolumn{6}{|c|}{ Genetic group } \\
\hline & \multicolumn{2}{|c|}{ Native $(\mathrm{N})$} & \multicolumn{2}{|c|}{ Texel $\times$ Native $(\mathrm{TN})$} & \multicolumn{2}{|c|}{ Santa Inês $\times$ Native $(\mathrm{SN})$} \\
\hline & Male & Female & Male & Female & Male & Female \\
\hline Tensile strength test & $1.62 \pm 0.02 b$ & $1.78 \pm 0.02 \mathrm{a}$ & $1.56 \pm 0.02 b$ & $1.70 \pm 0.02 \mathrm{a}$ & $2.01 \pm 0.02 \mathrm{a}$ & $1.70 \pm 0.02 b$ \\
\hline Tear strength test & $1.57 \pm 0.019 b$ & $1.70 \pm 0.02 \mathrm{a}$ & $1.52 \pm 0.019 \mathrm{~b}$ & $1.67 \pm 0.019 \mathrm{a}$ & $1.92 \pm 0.019 \mathrm{a}$ & $1.53 \pm 0.019 b$ \\
\hline
\end{tabular}

a,b - Significant difference between the sexes within each genetic group according to the Tukey test at 5\%. Coefficient of variation $=3.9 \%$.

Table 2 - Tensile and tear strength and thickness of the leather from sheep of the three genetic groups

\begin{tabular}{lcrr}
\hline Variable & \multicolumn{3}{c}{ Genetic group } \\
\cline { 2 - 3 } & \multicolumn{1}{c}{ Native } & Texel $\times$ Native & \multicolumn{2}{c}{ Santa Inês $\times$ Native } \\
\hline Tensile thickness $(\mathrm{mm})$ & $1.70 \pm 0.013 \mathrm{~b}$ & $1.63 \pm 0.013 \mathrm{c}$ & $1.85 \pm 0.014 \mathrm{a}$ \\
Tensile strength $\left(\mathrm{N} / \mathrm{mm}^{2}\right)$ & $18.87 \pm 0.33 \mathrm{a}$ & $16.40 \pm 0.33 \mathrm{~b}$ & 3.9 \\
Tear thickness $(\mathrm{mm})$ & $1.64 \pm 0.014 \mathrm{~b}$ & $1.60 \pm 0.013 \mathrm{~b}$ & 8.7 \\
Tear strength $(\mathrm{N} / \mathrm{mm})$ & $40.52 \pm 0.54 \mathrm{a}$ & $36.22 \pm 0.51 \mathrm{~b}$ & $1.73 \pm 0.013 \mathrm{a}$ \\
\hline
\end{tabular}

a,b Significant difference $(\mathrm{P}<0.05)$ among genetic groups for each variable. 
Elongation was greater in the perpendicular direction $(\mathrm{P}<0.05)$, demonstrating that leather has greater elasticity in this direction, a fact exploited in shoemaking, where the leather is stretched over the form in this direction. The tensile strength of the sheep leather exceeded the minimum recommended for shoes $(>40 \%)$ and it is in accordance with the values found for goat and sheep leather by Oliveira et al. (2008) and Oliveira et al. (2007).
The electromicrographs (Figure 3 ) show the surfaces of the leather from the three genetic groups. The same morphological aspect observed in the histological sections of the skins (Figure 2) can also be seen in the leather (Figures 3 and 4). The leather samples from the Native $\times$ Santa Inês animals had fewer hairs per unit of area than those from the Native group, while the leather from the Native $\times$ Texel group had the highest number of wool fibers per unit of area.

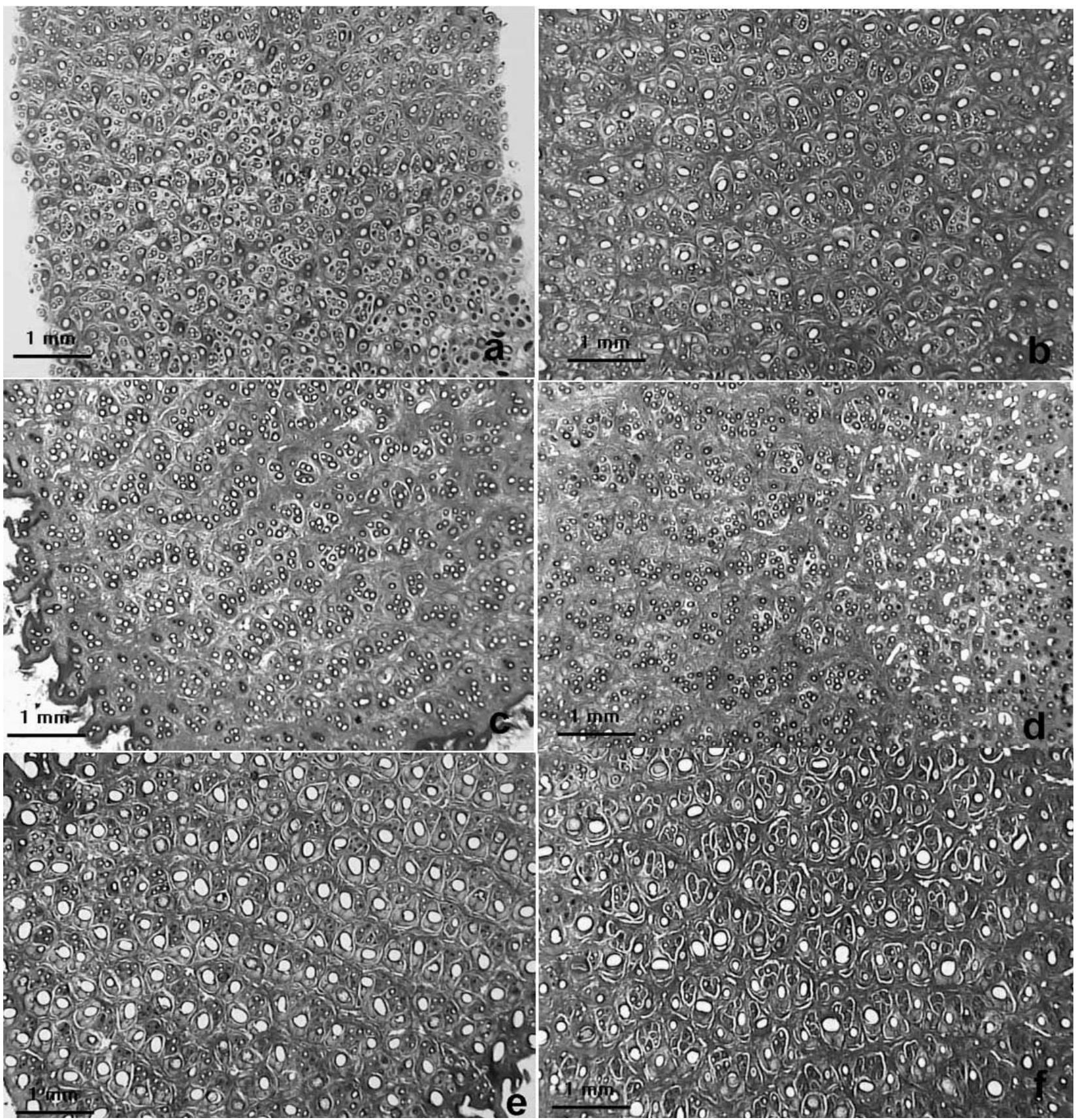

a, $\mathrm{c}$ and $\mathrm{e}=$ skins of the males; $\mathrm{b}, \mathrm{d}$ and $\mathrm{f}=$ skins of the females of the Native, Texel $\times$ Native and Santa Inês $\times$ Native genetic groups.

Figure 2 - Images of sections cut parallel to the surface of the skins of sheep of the Native, Texel $\times$ Native and Santa Inês $\times$ Native genetic groups. Staining = Masson’s trichrome. 
The electromicrographs shown in Figure 4 demonstrate the morphological structure of the leather samples from the three genetic groups, cut perpendicular to the surface and parallel to the backbone.

After tanning, the extrinsic quality of the leather samples was evaluated by means of commercial classification, which identifies the categories according to defects by a score and ranking. The leather samples from all three genetic groups obtained a score of "A", meaning they were free of defects or marks that could make them less marketable.

Table 3 - Means and standard deviations of each variable in the perpendicular and parallel directions to the backbone

\begin{tabular}{lccc}
\hline Position & Tensile strength $\left(\mathrm{N} / \mathrm{mm}^{2}\right)$ & Elongation (\%) & Tear strength $(\mathrm{N} / \mathrm{mm})$ \\
\hline Parallel & $21.44 \pm 0.27 \mathrm{a}$ & $53.30 \pm 2.27 \mathrm{~b}$ & $37.30 \pm 0.42 \mathrm{~b}$ \\
Perpendicular & $15.41 \pm 0.27 \mathrm{~b}$ & $80.73 \pm 2.34 \mathrm{a}$ & $41.86 \pm 0.43 \mathrm{a}$ \\
Coefficient of variation (\%) & $8.7 \%$ & $20.4 \%$ & $6.3 \%$ \\
\hline
\end{tabular}

a,b - Significant difference $(\mathrm{P}<0.05)$ between position for each variable.

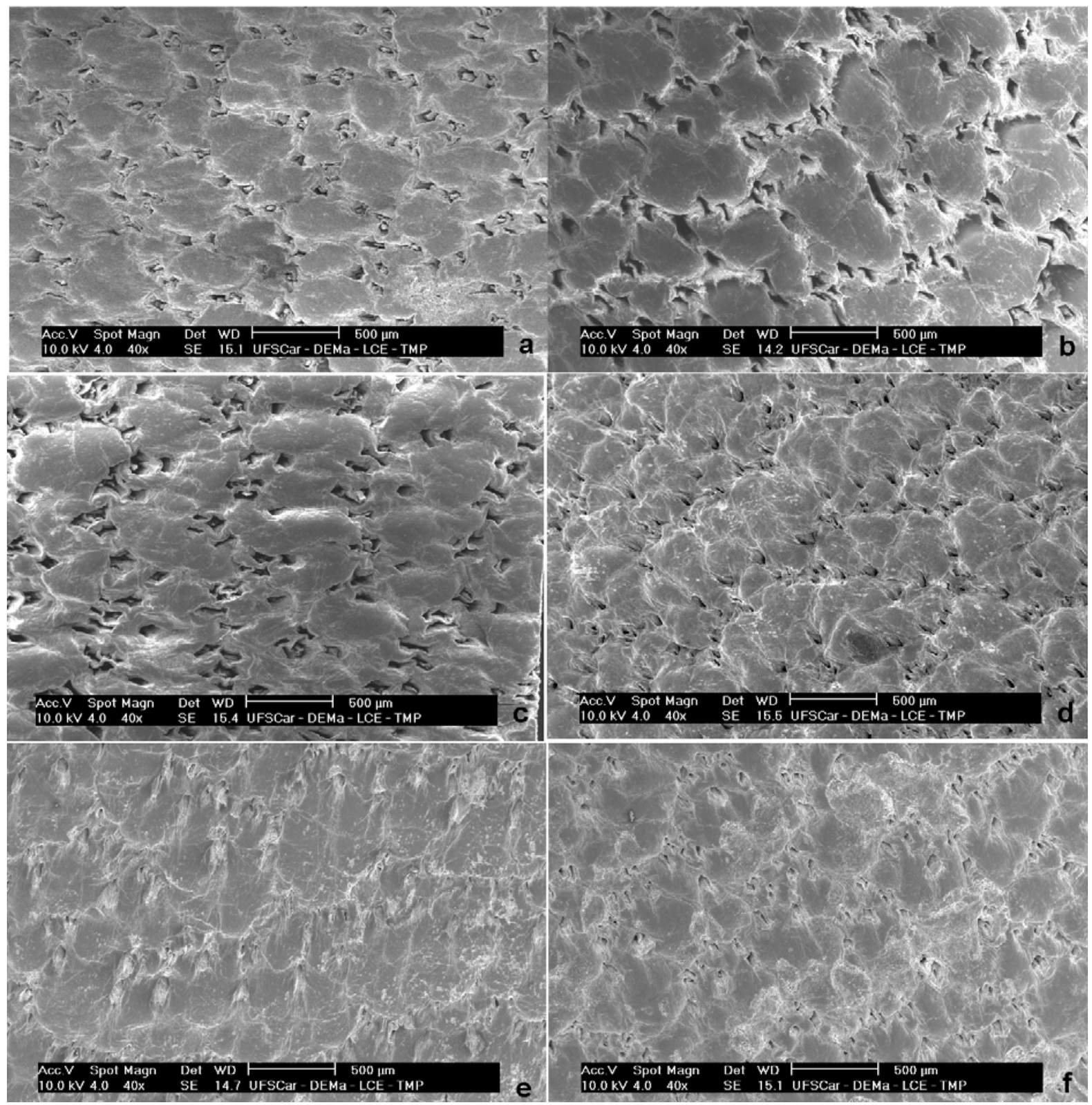

Figure 3 - Electromicrographs showing the surface of the leather samples from sheep of the genetic groups studied: Native, Texel $\times$ Native and Santa Inês $\times$ Native. Magnification $=40 \mathrm{x}$. 


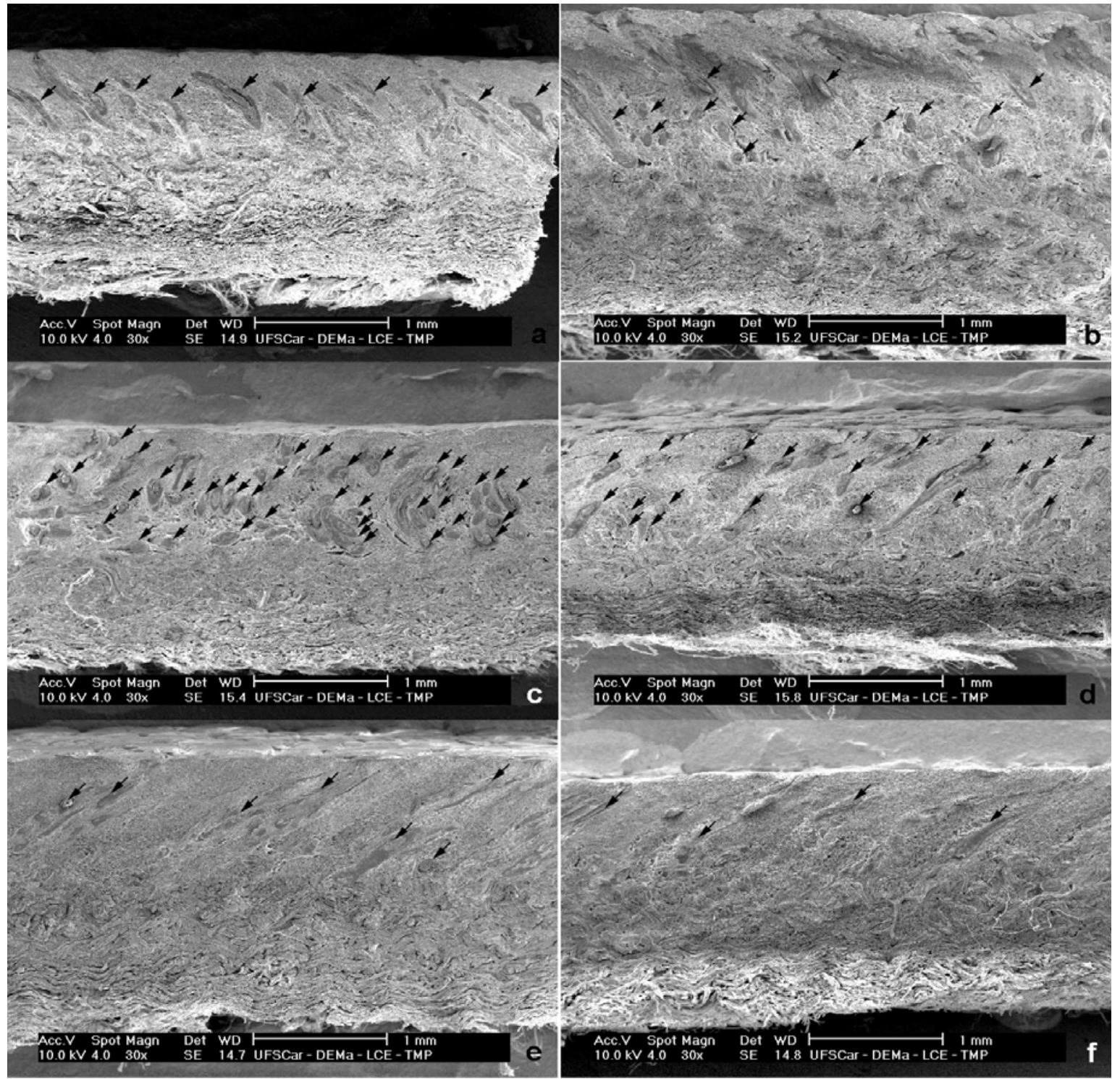

a, c and e = leather samples from the males, respectively; b, $\mathrm{d}$ and $\mathrm{f}=$ leather samples from the females of the Native $(\mathrm{N})$, Texel $\times$ Native $(\mathrm{TN})$ and Santa Inês $\times$ Native $(\mathrm{SN})$ groups. The arrows indicate the hair follicles or hair cut inside the follicle. Magnification $=40 \times$.

Figure 4 - Electromicrographs of sheep leather samples of the genetic groups studied.

\section{Conclusions}

Genetic group influence the intrinsic quality of the skins and leather of the sheep. The leather samples from sheep of the Santa Inês $\times$ Native group have better intrinsic quality than those of the Native and Texel $\times$ Native groups. The morphological aspect of the skins and leather help explain the tensile strength and tear strength of the leather samples.

\section{Acknowledgments}

The authors of this work thank the Universidade para o Desenvolvimento do Estado e da Região do Pantanal (UNIDERP), Fundação Manoel de Barros (FMB) and
Fundação de Apoio ao Desenvolvimento do Ensino, Ciência e Tecnologia do Estado de Mato Grosso do Sul (FUNDECT) for financial support of this study.

\section{References}

BADISCHE ANILIN \& SODA-FABRIK - BASF. Vade-mécum do curtidor. 4.ed. Ludwigshafen: BASF, 2004. 370p.

DAL MONTE, M.A.B.L.; COSTA, R.G.; JACINTO, M.A.C. et al. Características físico-mecânicas e químicas do couro de caprinos abatidos em idades diferenciadas. Revista Brasileira de Zootecnia, v.33, n.5, p.1285-1291, 2004.

FERRANDIZ-GOMEZ, T.P.; ALMELA, M.; MARTINMARTINEZ, J.M. et al. Effect of skin type and direction of applied force on peel strength of skin layers. Journal or the Society Leather Technologists and Chemistry, v.77, n.4, p.115-122, 1993. 
FIGUEIREDO, E.A.P.; SHELTON, M.; FERNANDES, A.A.O. Available genetic resources: the origin and classification of the world's sheep. In: SHELTON, M.; FIGUEIREDO, E.A.P. (Eds.). Hair sheep production in tropical and sub-tropical regions. 1.ed. Davis: University of California Press, 1990. p.7-24.

GOMES, W.S.; ARAÚJO, A.R.; CAETANO, A.R. et al. Origem e diversidade Genética da ovelha crioula do Pantanal, Brasil. In: SINPOSIO DE RECURSOS GENÉTICOS PARA AMÉRICA LATINA Y EL CARIBE, 2007, Chapingo, México. Anais... Chapingo, México, 2007. (CD-ROM).

INTERNATIONAL ORGANIZATION FOR STANDARDIZATION. ISO 2419: Leather - Physical and mechanical tests Sample preparation and conditioning. Geneva, 2006. 3p.

INTERNATIONAL ORGANIZATION FOR STANDARDIZATION. ISO 2589: Leather - Physical and mechanical tests Determination of thickness. Geneva, 2002. 2p.

INTERNATIONAL ORGANIZATION FOR STANDARDIZATION. ISO 3376: Leather - Physical and mechanical tests Determination of tensile strength and percentage extension. Geneva, 2002. 4p.

INTERNATIONAL ORGANIZATION FOR STANDARDIZATION. ISO 3377-2: Leather - Physical and mechanical tests Determination of tear load - Part 2: Double edge tear. Geneva, 2002. 3p.

JACINTO, M.A.C.; SILVA SOBRINHO, A.G.; COSTA, R.G. Características anátomo-estruturais da pele de ovinos (Ovis áries, L.) lanados e deslanados, relacionadas com o aspecto físico-mecânico do couro. Revista Brasileira de Zootecnia, v.33, n.4, p.1001-1008, 2004.

JACINTO, M.A.C. Alternativas de aproveitamento de pele caprina e seu impacto na rentabilidade da caprinocultura de corte. In: ENCONTRO DE CAPRINOCULTORES DO SUL DE MINA E MÉDiA MOGIANA, 5., 2001, Espírito Santo do Pinha. Anais eletrônicos... Espírito Santo do Pinhal: CREUPI, 2001.
Available at: <http://www.capritec.com.br/> Textos Técnicos/ Anais. Accessed on: Oct. 3, 2009.

JACINTO, M.A.C. Quinto cuarto - Pieles vacunas y ovinas. In: BIANCHI, G.; FEED, O.D. (Orgs.). Introducción a la ciencia de la carne. Buenos Aires: Hemisferio Sur, 2010. p.495-520.

KANAGARAJ, J.; SUNDAR, V.J.; MURALIDHARAN, C. et al. Alternatives to sodium chloride in prevention of skin protein degradation - case study. Journal of Cleaner Production, v.13, p. 825-831, 2005.

LEITE, E.R.; VASCONCELOS, V.R. Estratégias de alimentação de caprinos e ovinos em pastejo no Nordeste do Brasil. In: SIMPÓSIO INTERNACIONAL SOBRE CAPRINOS E OVINOS DE CORTE, 1., 2000, João Pessoa. Anais... João Pessoa: EMEPA, 2000. p.71-80.

NATIONAL RESEARCH COUNCIL - NRC. Nutrient requirements of sheep. Washington. D.C.: National Academy Press, 1985. 99p.

OLIVEIRA, R.J.F.; COSTA, R.G.; SOUZA, W.H. et al. Características físico-mecânicas de couros caprinos e ovinos no Cariri Paraibano. Revista Brasileira de Zootecnia, v.37, n.1, p.129-133, 2008.

OLIVEIRA, R.J.F.; COSTA, R.G.; SOUZA, W.H. et al. Influence of genotype on physico-mechanical characteristics of goat and sheep leather. Small Ruminant Research, v.73, p.181-185, 2007.

SILVA SOBRINHO, A.G.; JACINTO, M.A.C. Aproveitamento de peles ovinas. Jaboticabal: FUNEP, 2007.

SNYMAN, M.A.; JACKSON-MOSS, C.A. Comparison of leather properties of skins from ten different South African sheep breeds. South African Journal of Animal Science, v. 30, p.129-130, 2000

STATISTICAL ANALYSES SYSTEM - SAS. User's guide. Version 9.1.3, version for Windows. Cary, NC, USA: SAS Institute, 2002-2003. 135p. (CD-ROM).

VILlARROEL, A.B.S.; COSTA, R.G.; OLIVEIRA, S.M.P. Características físico-mecânicas do couro de ovinos mestiços Santa Inês e Texel. Revista Brasileira de Zootecnia, v.33, n.6, p.2373-2377, 2004. 